\title{
PEMBELAJARAN BERBASIS MASALAH UNTUK BELAJAR BAHASA INDONESIA DI SMA MUHAMMADIYAH TERNATE
}

\section{PROBLEMBASED LEARNING FOR LEARNING INDONESIAN LANGUAGE IN SMA MUHAMMADIYAH TERNATE}

\author{
Siti Mahnun \\ SMA Muhammadiyah Kota Temate \\ Jalan Toboko, Kota Baru, Ternate
}

\begin{abstract}
Abstrak
Selama ini pembelajaran bahasa Indonesia di kelas XII IPS SMA Muhammadiyah Ternate belum menerapkan pembelajaran konstruktivisme dan pembelajaran kontekstual. Oleh karena itu, masih sering ditemukan beberapa fakta dalam kegiatan pembelajaran: (1) siswa berbicara sendiri, (2) sebagian siswa bingung menangkap instruksi guru, (3) beberapa siswa tidak berani bertanya, (4) sedikit terjadi interaksi antarsiswa, dan (5) bahkan siswa jenuh dan bosan terhadap pelajaran bahasa Indonesia. Penelitian ini bertujuan mengetahui efektivitas belajar bahasa Indonesia siswa kelas XII IPS SMA Muhammadiyah Ternate melalui penerapan pembelajaran berbasis masalah. Penelitian ini menggunakan pendekatan kualitatif. Jenis penelitian ini adalah penelitian tindakan kelas. Hasil penelitian menunjukkan bahwa penerapan pembelajaran berbasis masalah dapat meningkatkan hasil belajar siswa kelas XII IPS SMA Muhammadiyah Ternate yang ditunjukkan oleh kemampuan siswa mengungkapkan pendapat dalam bentuk kritik dan esai.
\end{abstract}

Kata kunci: pembelajaran berbasis masalah, hasil belajar, penelitian tindakan kelas

\begin{abstract}
During this learning Indonesian in class XII IPS SMA Muhammadiyah Ternate not apply constructivism learning and contextual learning. Therefore, they often found several facts in learning activities: (1) the students speak for themselves, (2) some students confused capture the teacher's instructions, (3) some students did not dare ask, (4) a bit of an interaction between students, and (5) even students bored and tired of the Indonesian language teaching. This study aims to determine the effectiveness of learning Indonesian students in grade XII IPS SMA Muhammadiyah Ternate through the application of problem-based learning. This study used a qualitative approach. This research is a classroom action research. The results showed that the application of problem-based learning can improve learning outcomes of students of class XII IPS SMA Muhammadiyah Ternate exhibited by the students' ability to express an opinion in the form of criticism and essays.
\end{abstract}

Keywords: problem-based learning, learning outcomes, action research

\section{Pendahuluan}

Mata pelajaran bahasa Indonesia memiliki peran sentral dalam perkembangan intelektual, sosial, dan emosional peserta didik serta merupakan penunjang keberhasilan dalam mempelajari semua mata pelajaran lain. Pembelajaran bahasa Indonesia diharapkan membantu peserta didik mengenal dirinya, budayanya, dan budaya orang lain, mengemukakan gagasan dan perasaan, terampil menggunakan bahasa dalam masyarakat, serta menggunakan kemampuan berbahasa untuk analisis dan imaginasi.

Pembelajaran bahasa Indonesia diarahkan untuk meningkatkan kemampuan peserta didik untuk berkomunikasi dalam bahasa Indonesia dengan baik dan benar, baik secara lisan maupun tulis, serta menumbuhkan apresiasi terhadap karya sastra Indonesia. 
Standar kompetensi mata pelajaran Bahasa Indonesia merupakan kualifikasi kemampuan minimal peserta didik yang menggambarkan penguasaan pengetahuan, keterampilan berbahasa, dan sikap positif terhadap bahasa dan sastra Indonesia. Standar kompetensi ini merupakan dasarbagi peserta didik untuk memahami dan merespon situasi lokal, regional, nasional, dan global.

Pengalaman pembelajaran Bahasa Indonesia di kelas XII IPS bahwa selama ini guru belum menerapkan pembelajaran yang kontruktivisme, demikian juga pembelajaran kontekstual, sehingga pada pelaksanaan proses belajar mengajar juga masih terlihat ada siswa yang ngobrol sendiri dan sebagian siswa masih bingung dalam menangkap instruksi dari guru, masih terdapat beberapa siswa yang tidak berani untuk bertanya, sedikit pula terjadi interaksi antarsiswa dalam proses belajar mengajar, kadang juga dalam pembelajaran ada siswa yang kurang persiapan dalam belajar, bahkan siswa merasa jenuh dan bosan terhadap pelajaran Bahasa Indonesia.

Guru harus menyadari bahwa karakter individu dalam kelas untuk memahami konsep memiliki perbedaan, ada siswa yang memiliki kecepatan belajar tinggi, sedang, dan rendah. Untuk mengaktifkan siswa dalam belajar, guru dapat menerapkan berbagai strategi atau metode pembelajaran di kelas. Salah satu strategi pembelajaran yang berorientasi pada pandangan konstruktivis adalah pembelajaran berbasis masalah (PBM).

Pembelajaran berbasis masalah memberikan keuntungan bagi siswa, karena akan lebih mudah memahami suatu konsep jika mereka saling mendiskusikan masalah tersebut dengan temannya (Slavin, 1997). Siswa yang cepat dalam belajar, akan lebih meningkat lagi kemampuannya, karena mampu menjelaskan konsep dengan bahasanya sendiri, sedangkan siswa yang lambat juga akan mendapat keuntungan karena memperoleh penjelasan dari teman dengan bahasa yang lebih sederhana dan mudah dipahami.

Berdasarkan uraian pada latar belakang, maka peneliti merancang penelitian tindakan kelas dengan judul "Pembelajaran Berbasis Masalah untuk Belajar Bahasa Indonesia di SMA Muhammadiyah Ternate".

\section{Teori dan Metode Penelitian}

Pendekatan yang digunakan dalam penelitian adalah pendekatan kualitatif karena berupaya mengkaji lebih mendalam tentang peningkatan hasil belajar Bahasa Indonesia siswa kelas XII IPS SMA Muhammadiyah Ternate dengan penerapan model PBM. Jenis penelitian ini adalah Penelitian Tindakan Kelas (PTK), di mana dalam PTK terdapat tindakan-tindakan untuk perbaikan pembelajaran di kelas (Kasbollah,1992).

Berdasarkan pendekatan dan jenis penelitian, maka kehadiran peneliti di lapangan sangat diperlukan. Dalam penelitian ini, peneliti bertindak sebagai pengolah instrumen, perancang tindakan, sekaligus pelaksana dan pelapor penelitian.

Peneliti sebagai pengelola instrumen mengandung arti bahwa peneliti sebagai pengajar,dan pengumpul data. Peneliti sebagai perancang tindakan artinya peneliti yang membuat rancangan pembelajaran selama penelitian. Hal ini sesuai dengan pernyataan Maleong (1994) bahwa kedudukan peneliti dalam penelitian kualitatif adalah sebagai perencana, pelaksana, pengumpul data, analisis data dan pelapor hasil penelitian.

Instrumen penelitian ini adalah alat pengumpul data yang menggunakan tes dan nontes. Tes berupa tes hasil belajar dengan menggunakan soal tes yang dibuat oleh peneliti yang terdiri dari 5 soal esei. Teknik non-tes dengan menggunakan lembar pengamatan yang dibuat oleh peneliti selama pelaksanaan PTK.

Tahap-tahap yang ditempuh dalam penelitian ini mencakup: 1) tahap pendahuluan 
(pra tindakan) dan tahap tindakan. Rincian kegiatan tahap-tahap tersebut adalah sebagai berikut.

\subsection{Tahap Pendahuluan (Pra Tindakan)}

Tahap pendahuluan dilaksanakan dengan melakukan identifikasi masalah di kelas dan menentukan pemecahan masalah dengan mengunakan model PBM.

\subsection{Tahap Tindakan}

Pelaksanaan tindakan dalam penelitian ini dilakukan sesuai dengan jenis penelitian yang dipilih yaitu PTK dengan pendekatan kualitatif. Kegiatan Penelitian dilaksanakan secara bersiklus, setiap siklus terdiri dari empat tahap yaitu: (1) perencanaan, (2) pelaksanaan, (3) pengamatan, dan (4) refleksi. Model semacam ini mengikuti model yang dikembangkan oleh Kemmis \& Mc Taggart (1998:10-13) dalam Depdiknas (1999). Adapun penjabaran tahaptahap dalam siklus PTK dapat diuraikan sebagai berikut;

\section{Rencana Tindakan}

Pada siklus I ini, rencana tindakan yang dibuat adalah (a) menyusun RPP, (b) menyusun lembar pengamatan, dan (c) menentukan metode.

2. Pelaksanaan Tindakan

Pada tahap ini dilakukan kegiatan pembelajaran yang terdiri dari: (a) membuka pelajaran, (b) membentuk kelompok, (c) menyampaikan tujuan pembelajaran dan format diskusi kelompok, (d) pembimbingan diskusi kelompok, (e) presentase kelompok, (f) kuis dan penskorinan, dan $(\mathrm{g})$ penghargaan kelompok.

\section{Observasi}

Selama pelaksanaan tindakan diamati oleh teman sejawat selaku pengamat aktivitas siswa dan guru dalam melaksanakan PBM.

4. Refleksi

Pada tahap ini dilakukan evaluasi pelaksanaan tindakan selama siklus Idan direncanakan tindak lanjut perbaikan bila diperlukan melalui pelaksanaan siklus II.
Adapun teknik pengumpulan data dalam penelitian ini terdiri dari:

a. Data nilai hasil belajar yang diperoleh dari pelaksanaan tes formatif

b. Data nilai unjuk kerja siswa selama pelaksanaan pembelajaran

c. Data hasil pengamatan aktivitas siswa dan aktivitas guru yang diperoleh dari hasil pengamatan observer.

Teknik analisis data yang digunakan adalah teknik analisis data Kualitatif yang dikembangkan Milles \& Huberman (1992) dalam Depdiknas (1999) yang terdiri dari tiga tahap yaitu:

a. Mereduksi Data

Pada tahap ini dilakukan abstraksi data yang berupa nilai hasil belajar, nilai unjuk kerja dan data pengamatan observer. Tujuan abstraksi data adalah untuk memperoleh informasi yang jelas dari data.

b. Menyajikan data

Pada tahap ini dilakukan pengorganisasian hasil reduksi data sehingga memberi kemungkinan adanya penarikan kesimpulan dari pelaksanaan tindakan dalam PTK.

c. Penarikan kesimpulan dan Verifikasi data Kegiatan penarikan kesimpulan mencakup pencarian arti atau makna data serta memberi penjelasan. Makna dan arti yang diperoleh tersebut harus diuji kebenaran dan kecocokannya melalui verivikasi data.

Kriteria pelaksanaan PTK ditentukan sebagai berikut:

$$
85 \%<\mathrm{NR}<100 \%
$$

Pelaksanaan siklus I berisi tentang jalannya pembelajaran, hasil observasi kinerja siswa, hasil belajar siswa dan aktivitas guru dalam pembelajaran serta refleksi.

\section{Hasil dan Pembahasan}

\subsection{Siklus I}

\subsubsection{Perencanaan}


Pada siklus ini materi yang diajarkan adalah standar kompetensi 16 Mengungkapkan pendapat dalam bentuk kritik dan esai. Kompetensi dasarnya adalah 16.1 Memahami prinsip-prinsip penulisan kritik dan esai sangat baik

$75 \%<\mathrm{NR}<84 \%$ : Baik

$65 \%<\mathrm{NR}<74 \%$ : Cukup

$0 \%<\mathrm{NR}<64 \%$ : Kurang

\subsubsection{Pelaksanaan Tindakan}

Pada penelitian ini yang bertindak sebagai guru adalah guru mata pelajaran dan pengamat yang terlibat adalah 2 orang guru. Selanjutnya proses pembelajaran dilaksanakan dengan menerapkan metode PBM.

Penyajian fenomena yang dijadikan masalah adalah arti kritis dan karya kritis sebagai bagian pengungakapan pendapat

Tes akhir dilakukan pada tahap evaluasi untuk mengukur ketuntasan belajar siswa setelah mengikuti pembelajaran pada siklus I. Soal tes berupa 5 butir soal (terlampir dalam RPP). Hasil belajar siswa berupa tes akhir.

Dari analisis ketuntasan hasil belajar siklus pertana diketahui bahwa dari 30 siswa untuk hasil belajar kognitif setara dengan siklus I mencapai ketuntasan $80 \%$ yang berarti kategori baik. Demikian juga hasil belajar afektif (saling ketergantungan positif, tepat waktu, kerjasama) dan psikomotor (tepat menggunakan alat/bahan, interaksi tatap muka) telah mencapai ketuntasan $80 \%$.

\subsubsection{Observasi}

Observasi dilakukan untuk melihat seluruh kegiatan pada saat pelaksanaan tindakan yang meliputi observasi aktivitas siswa dan guru. Data observasi aktivitas siswa dalam pelaksanaan PBM.

Berdasarkan hasil observasi aktivitas siswa pada pelaksnaan siklus I, diketahui bahwa prosentase rata-rata skor observasi sebesar $85 \%$, hal ini dapat dikatakan bahwa aktivitas siswa pada pelaksanaan pembelajaran dengan PBM tergolong baik.

Dari hasil observasi aktivitas guru dapat diketahui rata-rata prosentase aktivitas guru sebesar $100 \%$ yang berarti aktivitas guru tergolong baik.

\subsubsection{Refleksi}

Berdasarkan hasil pelaksanaan tindakan dan observasi siklus I didapatkan beberapa hal yang merupakan hasil refleksi yaitu hasil belajar siswa, kinerja siswa dan aktivitas siswa tergolong baik. Demikian juga untuk aktivitas guru dalam melaksanakan PBM tergolong baik berdasarkan hasil observasi pengamat, sehingga hal tersebut perlu dipertahankan pada pelaksanaan siklus II.

\subsection{Siklus II}

Berdasarkan hasil refleksi pelaksanaan pembelajaran siklus I, maka dapat dipaparkan pelasanaan siklus II sebagai berikut.

\subsubsection{Perencanaan}

Pada siklus II materi yang diajarkan adalah KD 16.2 Menerapkan prinsip-prinsip penulisan kritik dan esai untuk mengomentari karya sastra. Metode pembelajaran sama dengan pelaksanaan siklus I, yaitu PBM.

\subsubsection{Pelaksanaan Tindakan}

Berdasarkan hasil observasi pelaksanaan siklus II dapat diketahui ketuntasan hasil belajar siswa mencapai $100 \%$. (prosedur penilaian hasil belajar sama dengan siklus I), dari hasil evaluasi pelaksanaan siklus II ini dapat diketahui hasil belajar siswa tergolong Baik.

\subsubsection{Observasi}

Berdasarkan data hasil observasi aktivitas siswa pada siklus II terdapat kenaikan rata-rata prosentase penilaian aktivitas siswa oleh observer yaitu 90\%, (rata-rata skor observer adalah 36 dari skor maksimal 40) yang berarti aktivitas siswa tergolong cukup (sumber lampiran 9). 
Hasil observasi aktivitas guru pada pelaksanaan siklus II pembelajaran dengan PBM rata-rata skor observer 15 dari skor maksimal 15 yang berarti mencapai prosentase $100 \%$ yang berarti aktivitas dan persiapan guru sudah tergolong baik (sumber lampiran 10).

\subsubsection{Refleksi}

Berdasarkan pada pelaksanaan tindakan dan observasi siklus II, diketahui bahwa aktivita s siswa telah mencapai peningkatan dan ketuntasan demikian juga aktivitas guru dalam menerapkan pembelajaran berbasis masalah sudah termasuk kategori BAIK, sehingga pelaksanaan PTK tidak perlu dilanjutkan ke siklus III.

Hasil penelitian tentang Penerapan pembelajaran Berbasis masalah (PBM) untuk meningkatkan aktivitas ilmiah dan hasil belajar siswa dapat dijelaskan sebagai berikut.

Kemampuan kognitif siswa kelas XII IPS SMA Muhammadiyah Ternate yang diperoleh melalui nilai tes dan unjuk kerja baik pada siklus I maupun siklus II telah mencapai ketuntasan 100\%. Demikian pula aktivitas guru dalam melaksanakan PBM, baik pada siklus I maupun II juga telah baik kualitasnya.

\section{Simpulan}

Berdasarkan hasil analisis, disimpulkan bahwa penerapan PBM dapat meningkatkan hasil belajar bahasa Indonesia siswa kelas XII IPS SMA Muhammadiyah Ternate untuk konsep mengungkapkan pendapat dalam bentuk kritik dan esei.

Saran yang dapat disampaikan melalui hasil penelitian ini adalah sebaiknya guru SMA mau dan mampu mengimplementasikan PBM dalam kegiatan pembelajarannya

\section{Daftar Pustaka}

Arikunto, Suharsimi. 1999. Prosedur Penelitian Suatu Pendekatan Praktik. Yogyakarta: Rineka Cipta.
Arikunto, Suharsimi. 2002. Dasar-Dasar Evaluasi Pendidikan. Jakarta: Bumi Aksara. Asikin. 2002. Pembelajaran Matematika berbasis Kontruktivisme kontekstual. Materi Pelatihan Guru SLTP dalam rangka implementasi Kurikulum Berbasis Kompetensi untuk SMP.

BSNP, 2006. Standart Isi KTSP. Jakarta: Depdiknas

Dahar, Ratna W. 1988. Teori-teoriBelajar. Jakarta: Depdikbud.

Depdiknas. 1999. Penelitian Tindakan Kelas (Classroom Action Research). Jakarta: Direktorat Jendela Pendidikan Dasar dan Menengah.

Depdiknas, 2003. Kurikulum 2004 Standar Kompetensi Mata Pelajaran Biologi. Jakarta: Departemen Pendidikan Nasional.

Depdiknas. 2004. Panduan Broad Based Education. Jakarta: Depdiknas

Hudoyo, 1979. Penilaian hasil Belajar. Bandung: Rosdakarya

Ibrahim, Muslimin, dkk. 2000. PembelajaranKooperatif. Surabaya: University Press.

Muhardjito,2008. TeknikEvaluasipendidikan. Jakarta: Rosdakarya

Moleong, L.J. 2004. MetodologiPenelitianKualitatif. Bandung: PT RemajaRosdakarya.

Subiyanto, 1988. EvaluasiHasilBelajar. Malang: IKIP Malang

Sumarto, 1998. StrategiPenilaianHasilBelajar. Jakarta BumiAksara

Slavin, R.E. 1997. Educational Psychology, Theory an Practice. Fifth Edition, Boston: Allyn and Bacon.

Susanto, P. 2004. Pembelajaran Konstruktivis dan Kontekstual sebagai Pendekatan dan Metodologi Pembelajaran Sains dalam $K B K$. Materi Seminar dan Workshop Calon Fasilitator Kolaborasi FMIPA UM-MGMP Kota Malang.

Usman, 1994. Teknik Evaluasi Hasil Belajar. Jakarta. Banyumedia

Yayuk, M 2005. Penerapan Pendekatan STM untuk Meningkatkan Hasil Belajar Biologi Konsep Bioteknologi pada siswa SMAN 1 Batu Kelas XII. Malang: UM 
Yuliarini, 2006. Penerapan Penilaian Berbasis Kelas pada Pengajaran IPA di SMPN 3 Malang. Malang: UM. Skripsi tidak diterbitkan

Zuhriah, Nurul. 2003. PenelitianTindakan. Malang: Bayumedia Publishing. 